\title{
Diltiazem-induced palmar desquamation and oral erosions
}

\author{
Sebastian Miguel Toescu, ${ }^{1}$ Simon Kennon, ${ }^{2}$ Howard Stevens ${ }^{3}$
}

${ }^{1}$ Academic Foundation Trainee, Royal Free Hospital, London, UK

${ }^{2}$ Department of Cardiology, Chase Farm Hospital, Enfield, UK

${ }^{3}$ Department of Dermatology, Chase Farm Hospital, Enfield, UK

Correspondence to Dr Sebastian Miguel Toescu, s.toescu@nhs.net
To cite: Toescu SM, Kennon S, Stevens H. BMJ Case Rep Published online: [please include Day Month Year] doi:10.1136/bcr-2013201536

\section{DESCRIPTION}

A 64-year-old man presented with a 12-month history of angina. Following coronary angiography he underwent percutaneous coronary intervention with deployment of drug-eluting stents to the left anterior descending and main diagonal branch. $\mathrm{He}$ was discharged on diltiazem $200 \mathrm{mg}$ daily as an antianginal and antihypertensive drug, aspirin, clopidogrel and atorvastatin; as well as his regular medications omeprazole and fluoxetine.

When reviewed 2 weeks later he was free of angina but had developed skin shedding and peeling affecting the palmar surfaces of both the hands (figure 1), and oral erosions (figure 2) of the tongue and mouth; the feet were spared. Diltiazem-induced palmar-plantar desquamation (PPD) was diagnosed; diltiazem was discontinued, a urea-containing emollient was prescribed and the skin condition resolved completely over the next fortnight.

PPD is clinically manifested as an exfoliative peeling of the stratum corneum of the glabrous epidermis. This may be part of a spectrum of skin disease seen with diltiazem from PPD through to generalised exfoliative dermatitis. PPD has been reported previously with diltiazem. ${ }^{1}$ To the best of our knowledge, there are no reports of concomitant involvement of the buccal mucosa, though this may be explained by similar keratins (types 6 and 16) being expressed in both the palmar-plantar epidermis and in the mouth.

PPD can be caused by other calcium channel blockers, although with less propensity than diltia-

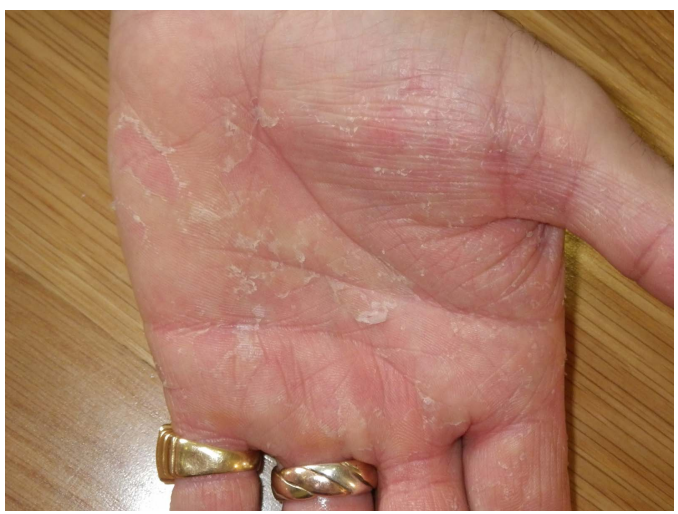

Figure 1 Photograph showing palmar desquamation affecting the left hand.

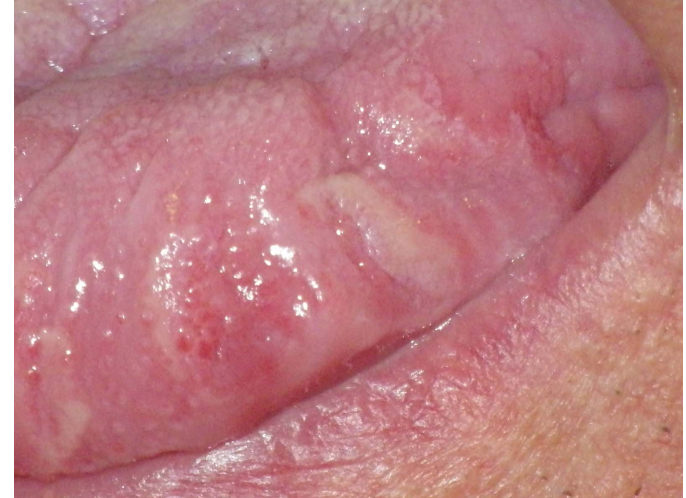

Figure 2 Photograph showing erosions on the left lateral aspect of the tongue.

zem. It also occurs as a side effect of amiodarone, enalapril and phenindione, and with chemotherapeutic drugs.

Clinicians should be aware of the adverse cutaneous effects of diltiazem suggested by this case.

\section{Learning points}

- Diltiazem can cause significant adverse dermatological reactions.

- This is the first reported case of concomitant palmar desquamation and oral erosions.

- Prescribing clinicians should be aware of these newly described side effects of diltiazem suggested by this case, and should withdraw the use of diltiazem when suspected.

Contributors SMT reviewed the literature, collated and wrote the article. SK saw the patient in general cardiology clinic, and referred to $\mathrm{HS}$ for advice regarding the dermatological condition.

Competing interests None.

Patient consent Obtained.

Provenance and peer review Not commissioned; externally pee reviewed.

\section{REFERENCE}

1 Scolnick B, Brinberg D. Diltiazem and generalized lymphadenopathy. Ann Int Med 1985;102:558. 
Copyright 2013 BMJ Publishing Group. All rights reserved. For permission to reuse any of this content visit http://group.bmj.com/group/rights-licensing/permissions.

BMJ Case Report Fellows may re-use this article for personal use and teaching without any further permission.

Become a Fellow of BMJ Case Reports today and you can:

- Submit as many cases as you like

- Enjoy fast sympathetic peer review and rapid publication of accepted articles

- Access all the published articles

- Re-use any of the published material for personal use and teaching without further permission

For information on Institutional Fellowships contact consortiasales@bmjgroup.com

Visit casereports.bmj.com for more articles like this and to become a Fellow 